\title{
Upaya Pencegahan dan Penanggulangan COVID-19 dan Mewujudkan Merdeka Belajar Melalui KKN Tematik di Desa Siluman Kecamatan Pabuaran Kabupaten Subang
}

\author{
Andri Purwanugraha*1, Herdian Kertayasa ${ }^{2}$ \\ ${ }^{1}$ Program Studi Pendidikan Guru Sekolah Dasar (PGSD), Fakultas Keguruan dan Ilmu Pendidikan, \\ Universitas Mandiri Subang, Indonesia \\ 2Program Studi Pendidikan Agama Islam, Fakultas Keguruan dan Ilmu Pendidikan, Universitas Buana \\ Perjuangan Karawang, Indonesia \\ *e-mail: andripurwanugraha22@gmail.com ${ }^{1}$, herdian.kertayasa@ubpkarawang.ac.id ${ }^{2}$
}

\begin{abstract}
Abstrak
Pandemi COVID-19 yang bermula di Wuhan, Tiongkok, telah menyebar ke 219 negara di dunia termasuk di Indonesia. Berbagai upaya telah dilakukan oleh pemerintan Indonesia dalam pencegahan dan penanggulangannya. Salah satu lembaga yang berperan penting dalam upaya pencegahan dan penanggulangan penyebaran COVID-19 ini adalah Perguruan Tinggi. Melalui kegiatan KKN tematik, tim pengabdian melakukan pengabdian kepada masyarakat di Desa Siluman Kec. Pabuaran Kab. Subang. Sebelum pelaksanaan KKN tematik diawali dengan melakukan survey awal di lapangan. Setelah itu kemudian ada beberapa permasalahan yang ditemukan yaitu masih minimnya perhatian terkait protokol kesehatan seperti kurangnya kesadaran penggunaan masker dan masih kurangnya kesadaran menjaga lingkungan bersih. Metode pelaksanaan melalui sosialisasi kepada Desa dan tokoh masyarakat, membantu pendataan warga dan pengembangan dalam bidang pendidikan dan sosial. Hasil pengabdian ini mampu menghasilkan hubungan harmonis antara Tim KKN dan warga Desa Siluman dengan tercapainya beberapa program seperti mahasiswa mampu mengembangkan kualitas pembelajaran sebagai sarana program merdeka belajar, ikut kegiatan gotong royong, mengikuti kegiatan keagamaan, pemberian alat kesehatan, mengembangkan program kegiatan hidup sehat dan lingkungan bersih berupa kegiatan senam sehat dan lain sebagainya. Implikasi dari kegiatan KKN ini mampu berkontribusi bersama dalam kepedulian menjaga kesehatan masyarakat sehingga lebih bersinergi dalam mewujudkan masyarakat yang sehat, mandiri, unggul serta dinamis.
\end{abstract}

Kata kunci: KKN Tematik, Pencegahan Virus COVID-19, Pengabdian Masyarakat

\begin{abstract}
The COVID-19 pandemic that started in Wuhan, China, has spread to 219 countries in the world, including Indonesia. Various efforts have been made by the Indonesian government in prevention and control. One of the institutions that play an important role in efforts to prevent and control the spread of COVID-19 is Universities. Through thematic KKN activities, the community service team in Siluman Village, Kec. Kab. Subang. Before the implementation of thematic KKN begins with conducting an initial survey in the field. After that, several problems were found, namely the lack of attention related to health protocols such as the lack of awareness of the use of masks and the lack of awareness of maintaining a clean environment. The method of implementation is through outreach to Villages and community leaders, assisting in data collection on residents and development in the education and social fields. The results of this service are able to produce a harmonious relationship between the KKN Team and the residents of Siluman Village with the achievement of several programs such as students being able to develop the quality of learning as a means of independent learning programs, participating in mutual cooperation activities, participating in religious activities, providing medical equipment, developing programs for healthy living and the environment. clean in the form of healthy exercise and so on. The implications of this KKN activity are being able to contribute together in caring for public health so that they are more synergized in creating a healthy, independent, superior and dynamic society.
\end{abstract}

Keywords: Community Dedication, COVID-19 Virus Prevention, Thematic Community Service Program 


\section{PENDAHULUAN}

Pengabdian Masyarakat merupakan kegiatan intrakurikuler yang memberi kesempatan kepada mahasiswa untuk belajar dan beketja bersama-sama dengan masyarakat. Pengabdian masyarakat yang dilakukan oleh mahasiswa bukan berarti mengajar masyarakat tentang sesuatu yang terbaik untuk mereka, tetapi melakukan pemberdayaan sebagai sebuah proses pencarian (research) yang dilakukan bersamasama untuk mencari jalan terbaik dalam penyelesaikan persoalan yang mereka hadapi. Mahasiswa melakukan tugas pendampingan terhadap apa yang dibutuhkan oleh masyarakat dalam menghadapi problem sosial yang ada di tengah-tengah mereka. Menurut (Indonesia, 2012) pengabdian kepada masyarakat adalah kegiatan sivitas akademika yang memanfaatkan ilmu pengetahuan dan teknologi untuk memajukan kesejahteraan masyarakat dan mencerdaskan kehidupan bangsa.

Salah satu kegiatan yang menunjang dalam implementasi pengabdian terhadap masyarakat melalui pelaksanaan KKN. Kegiatan Kuliah Kerja Nyata (KKN) merupakan salah satu bentuk kegiatan yang memberikan pengalaman kepada mahasiswa untuk bersosialisasi dan hidup di tengah-tengah masyarakat secara terstruktur melalui beberapa tahap diantaranya persiapan, pembekalan, observasi sampai dengan tahap evaluasi. Kegiatan ini juga merupakan sebuah bentuk pengabdian mahasiswa kepada masyarakat yang sedang melakukan pembangunan diberbagai aspek seperti di bidang pendidikan, sosial, kerohanian dan ekonomi, serta secara langsung mengidentifikasi dan turut menangani masalah-masalah yang ada di masyarakat. Dalam pelaksanaan KKN, diharapkan mahasiswa dapat memberikan bantuan pemikiran, tenaga, dan ilmu pengetahuan dalam merencanakan dan melaksanakan progam pengembangan desa.

Begitupun pelaksanaan KKN Universitas Mandiri Kabupaten Subang memiliki peran penting dalam mensosialisasikan penanganan COVID-19. Oleh karena itu, Kuliah Kerja Nyata (KKN) dilaksanakan dengan tema "tematik". Kuliah Kerja Nyata (KKN) Tematik merupakan salah satu bentuk pengabdian kepada masyarakat yang dilakukan oleh mahasiswa secara interdisipliner, institusional, dan kemitraan sebagai salah satu wujud dari tridharma perguruan tinggi (Rangki \& Dalla, 2020). Hal yang menjadi pedoman dalam kegiatan Kuliah Kerja Nyata (KKN) ini adalah: a) Keputusan Presiden Republik Indonesia Nomor 7 tahun 2020 tentang gugus tugas percepatan penanganan Corona Virus Disease (COVID-19) (RI, 2020), b) Keputusan Presiden Republik Indonesia Nomor 11 tahun 2020 tentang penetapan kedaruratan kesehatan masyarakat Corona Virus Disease (COVID-19), c) Keputusan Kepala Badan Nasional Penanggulangan Bencana Nomor :13A Tahun 2020 tentang perpanjangan status keadaan tertentu darurat bencana wabah penyakit akibat Virus Corona Di Indonesia, d) Surat Edaran Mendikbud Nomor 37676,A2/ku/2020 Hal: Refocussing anggaran dan penggunaan anggaran untuk mendukung bekerja dari rumah, e) Dalam rangka pencegahan Corona Virus Disease 2019, e) Surat Edaran Mendikbud Nomor 3 tahun 2020 tentang pencegahan Corona Virus Disease (COVID-19) pada satuan pendidikan, (Pendidikan, 2020) f) Surat Mendikbud No :36362/Mpk A/Hk/2020 Hal: pembelajaran secara daring dan Bekerja dari rumah dalam rangka pencegahan penyebaran Virus COVID-19, g) Surat Edaran Rektor Universitas Mandiri Nomor 010 Tahun 2021 tentag Pelaksanaan Kegiatan Akademik di Masa Darurat COVID-19.

Tujuan dilaksanakan KKN Tematik ini untuk membantu progam peningkatkan mutu pendidikan dasar di Provinsi Jawa Barat, membantu pemerintah provinsi Jawa Barat, baik pada tahap perencanaan, pelaksanaan, evaluasi maupun mempertajam umpan balik peningkatan mutu pendidikan dasar yang sedang dijalankan pada kurun waktu ini, pendataan terkait masyarakat yang terdampak COVID-19, mengedukasi masyarakat mengenai protokol kesehatan, dan membantu kegiatan pembelajaran tatap muka terbatas serta mendorong penguatan di bidang sosial kemasyarakatan.

Dari kegiatan KKN Tematik ini diharapkan mampu mendorong mahasiswa dalam pengembangan ilmu pengetahuan yang dibutuhkan di masyarakat, mengingat selama ini muatan teori yang diterima di Universitas. Sehingga dengan pelaksanaan KKN di Desa Siluman mahasiswa bisa membantu kesulitan masyarakat terutama dalam pencegahan dan penanggulangan kasus COVID-19 dengan memberikan edukasi sosial, ikut terjun langsung ke 
lapangan pendidikan dalam semarak merdeka belajar dan mendukung terjaganya kesehatan masyarakat serta membantu pengembangan program desa secara bersama dalam mewujudkan masyarakat desa yang maju, sehat, dan dinamis.

\section{METODE}

Metode yang dilaksanakan dalam mencapai tujuan yang diharapkan dapat dirinci sebagai berikut:

a. Sosialisasi program Kuliah Kerja Nyata (KKN) Desa Siluman. Tim KKN melakukan beberapa kegiatan yang diprogramkan menurut kondisi dan struktural yang ada di masyarakat, salah satunya adalah melakukan pengenalan terhadap masyarakat sekitar dan melakukan orientasi terhadap bidang-bidang garapan di desa, seperti bidang pemerintahan, kesehatan, pendidikan, pertanian, UMKM, keagamaan dan lain-lain. Ada beberapa yang dilakukan oleh kelompok kami antara lain: 1) Sosialisasi kepada tokoh masyarakat Desa Siluman dan para pengusaha UMKM, 2) Perencanaan, 3) Pelaksanaan Pogram. Peserta Kuliah Kerja Nyata (KKN) melakukan sosialisasi kepada tokoh masyarakat Desa Siluman.

b. Pendataan pada masyarakat desa Siluman, sesuai dengan tema dan visi KKN Universitas Mandiri tahun 2021 kami melaksanakan pendataan mengenai dampak corona, dibawah arahan desa kami melakukan pendataan ke pada masyarakat terkait jumlah penduduk yang ada di Desa Siluman.

c. Membantu meningkatkan pembelajaran, dengan merancang program untuk membantu kegiatan pembelajaran tatap muka terbatas dan bimbingan belajar terutama di Dusun Siluman I selain itu kami membantu meningkatkan pembelajaran pendidikan dasar di Desa Siluman Kecamatan Pabuaran. Terdapat 4 SD, yaitu SDN Margaluyu, SDN Margasari I, SDN Margabudaya, SDN Margawinaya.

d. Membantu kegiatan gotong royong di Desa Siluman. Gotong royong adalah bekerja sama untuk mencapai hasil yang diinginkan (Kompas.com, 2021).

e. Memperbaharui struktur Desa.

f. Melakukan kegiatan belajar bersama anak-anak Desa Siluman.

g. Membantu setiap program-program di Desa Siluman.

Melakukan program kegiatan hidup sehat dan lingkungan bersih. Menerapkan hidup sehat sederhana menjadi langkah awal untuk memulai hidup sehat berkualitas (Kesehatan, 2018). Hal ini sangat penting mengingat dalam rangka pencegahan dari segala virus.

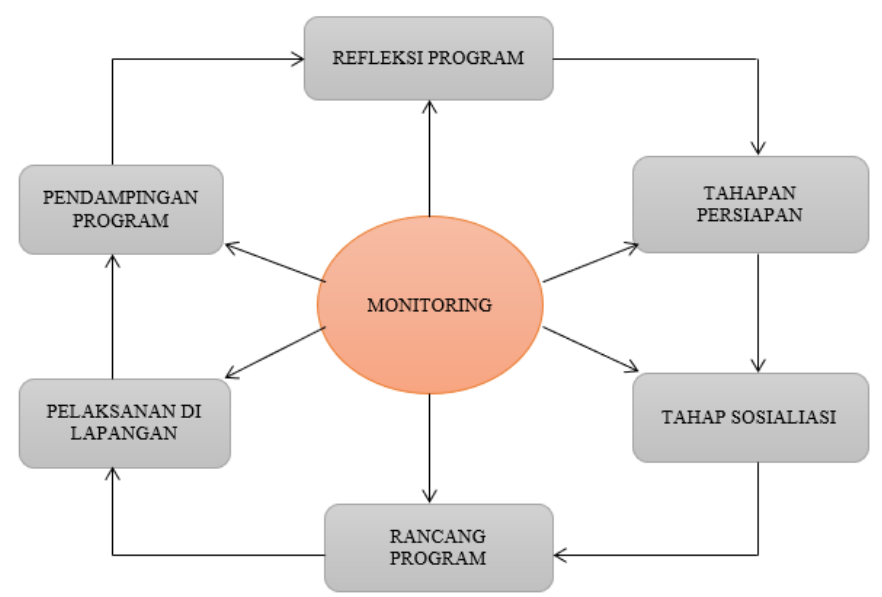

Gambar 1. Flowchart Kegiatan Pengabdian Masyarakat

\section{HASIL DAN PEMBAHASAN}

Siluman adalah salah satu desa di kecamatan Pabuaran, Subang, Jawa Barat, Indonesia. Sebagain besar penduduknya bermata pencaharian petani. Home industri yang berkembang 
adalah pengrajin meubel (Wiki, n.d.). Desa Siluman didirikan oleh Nasyihen Ainun Najib Pole pada tahun 1908 M, dan kata Siluman diambil dari nama sebuah kali kecil CISILUMAN yang sekarang termasuk kewilayah Desa Kadawung. Luas wilayah Desa Siluman pada tahun 1908 M adalah kurang lebih 1.730,228 Ha termasuk Desa Kadawung sekarang. Kali Cisiluman tersebut dipergunakan tempat persembunyian para pejuang desa dalam melawan penjajah Belanda, maka untuk mengenang sejarah, kali Cisiluman tersebut ditetapkan sebagai nama sebuah Desa, yang sekarang dikenal Desa Siluman.

Secara administratif Desa Siluman merupakan salah satu dari 10 Desa di Wilayah Kecamatan Siluman Kabupaten Subang yang terletak $\pm 1 \mathrm{Km}$ kearah selatan dari Kecamatan Siluman. Desa Siluman berada di ketinggian 29 mdpl diatas permukaan laut dengan wilayah \pm 24.697 Hektar.

Suhu rata-rata harian di daerah Desa Siluman adalah 24-31'C. Iklim Desa Siluman, sebagaimana desa-desa lain di wilayah Indonesia mempunyai Iklim Kemarau dan Penghujan. Hal tersebut mempunyai pengaruh langsung terhadap pola tanam yang ada di Desa Siluman Kecamatan Siluman. Iklim suatu daerah sangat berpengaruh dalam kehidupan utamanya untuk pertumbuhan pertanian. Selain itu, kondisi geografis Desa Siluman umumnya merupakan lahan pertanian.

Pada umumnya tingkat pendidikan masyarakat Desa Siluman dapat dikategorikan cukup baik, terbukti dengan banyaknya lulusan sekolah tingkat tinggi. Namun demikian masih ada juga sebagian kecil masyarakat kategori kurang mampu yang tidak mau melanjutkan sekolah ke tingkat yang lebih tinggi dikarenakan kurangnya tingkat pengetahuan akan pentingnya pendidikan.

Maka secara lebih kongkrit capaian program pengabdian masyarakat melalui KKN Tematik Universitas Mandiri ini adalah sebagai berikut:

\subsection{Mengadakan Kegiatan Kunjungan dan Sosialiasi}

Kami menyelenggarakan kegiatan kunjungan pada tokoh masyarakat yang ada di Desa Siluman Dalam pelaksanaanya, kami mendatangi rumah aparatur desa seperti Kepala Desa, Ketua RW dan RT. Tujuan kami menyelenggarakan kegiatan ini adalah untuk silaturahmi kepada tokoh masyarakat di Desa Siluman dan meminta bimbingan selama satu bulan selama ada di Desa Siluman.

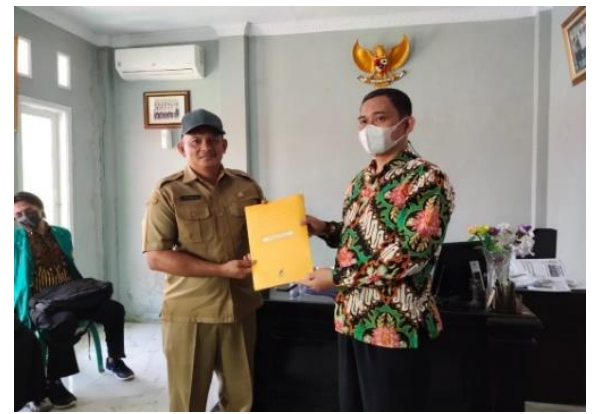

(a)

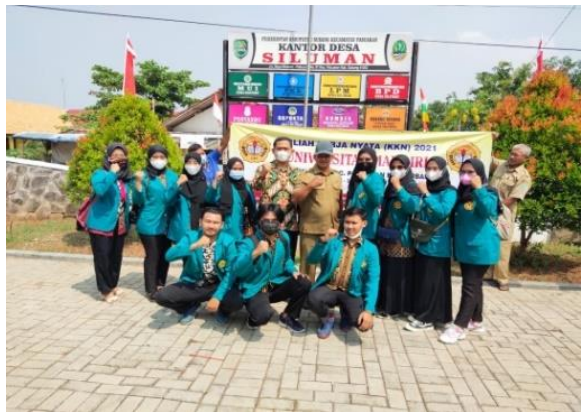

(b)

Gambar 2. Sosialisasi (a) Kepala Desa Siluman menerima kunjungan dan sosialisasi dalam pelaksanaan KKN Tematik Universitas Mandiri Subang (b) Mahasiswa peserta KKN diterima baik oleh Desa dan Perwakilan Masyarakat

\subsection{Program Kerja Bidang Pendidikan}

\subsubsection{Membantu Kegiatan (PTM) Tatap Muka Terbatas Tingkat SD/SMP/MTs}

Dalam pelaksanaan program kerja KKN kelompok 10 Universitas Mandiri, kami membantu kegiatan PTM terutama anak sekolah dasar di Desa Siluman, ternyata masih terdapat beberapa anak yang belum bisa membaca akibat PJJ saat ini. Kegiatan membantu Pembeajaran PTM di Desa Siluman dimulai dari pukul 08.00 - pukul 11.30 dari hari Senin hingga hari Jum'at. 


\subsubsection{Mengadakan Bimbingan Belajar}

Salah satu program pengembangan kami dalam bidang pendidikan adalah melakukan bimbingan belajar, karena dalam kegiatan PTM saat ini banyak terjadi kendala dalam waktu penyampaian pembelajaran. Bimbingan belajar adalah proses pemberian bantuan kepada murid dalam memecahkan kesulitan-kesulitan yang berhubungan dengan masalah belajar (Mulyadi, 2010). Dengan demikian Tim pengabdian melakukan kegiatan bimbel dalam rangka membantu kesulitan belajar siswa-siswi Desa Siluman serta salah satu implementasi dari program Merdeka Belajar.

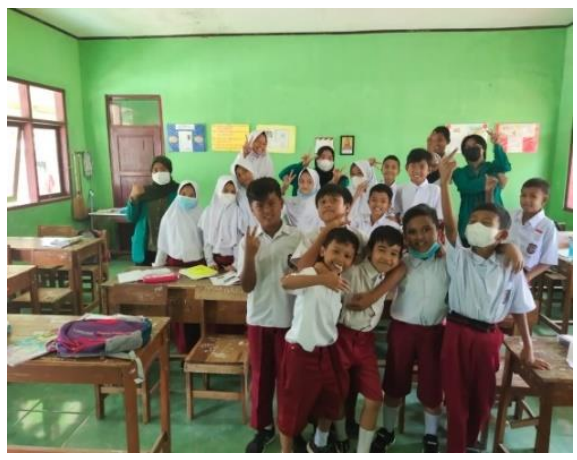

(a)

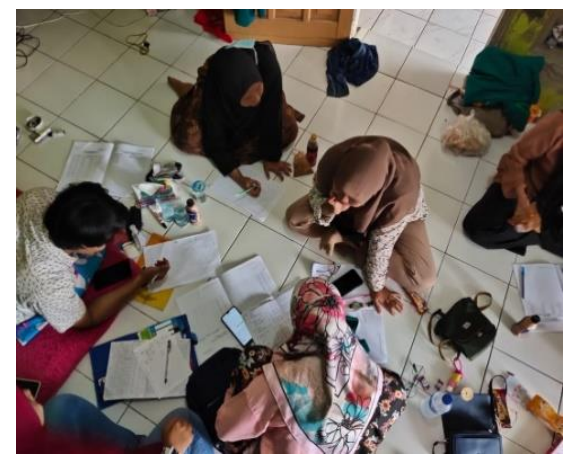

(b)

Gambar 3. Pengembangan Pendidikan (a) Tim KKN mendorong dan mendukung pelaksanaan kegiatan PTM terbatas (b) Mahasiswa peserta KKN mengadakan bimbingan belajar sebagai kepeduliaan memberantas buta aksara

\subsection{Bidang Sosial}

\subsubsection{Ikut Serta dalam Sosialisasi Protokol Kesehatan COVID-19}

Ikut serta dalam kegiatan sosialisai Prokes dimana dalam kegiatan ini kami membantu pihak desa dalam meyelenggarkan kegiatan ini, kegiatan ini pun dihadiri hampir seluruh pejabat di Desa Siluman seperti Kepala Desa beserta Aparatur Desa dan jajarannya seperti RT, RW. Hal ini dilakukan untuk menyukseskan kegiatan sosialisasi ke Masyarakat.

\subsubsection{Ikut Serta Dalam Membantu Kegiatan Gotong Royong}

Ikut serta dalam membantu kegaitan gotong royong pada hari rabu tanggal 15 September 2021 pukul 08.00 s.d selesai. Di sana kami membantu aparatur desa dalam membersihkan lingkungan agar tertata lebih rapih dan berih.

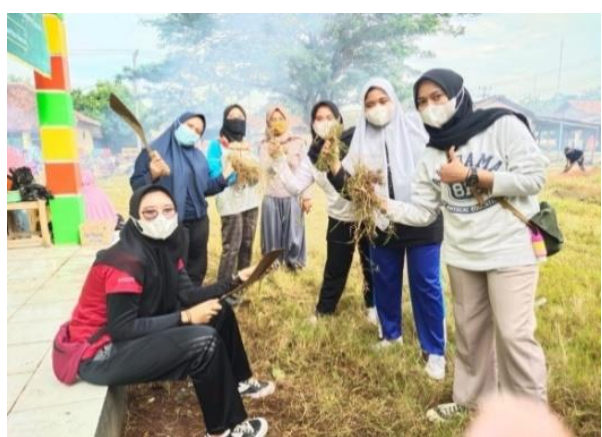

(a)

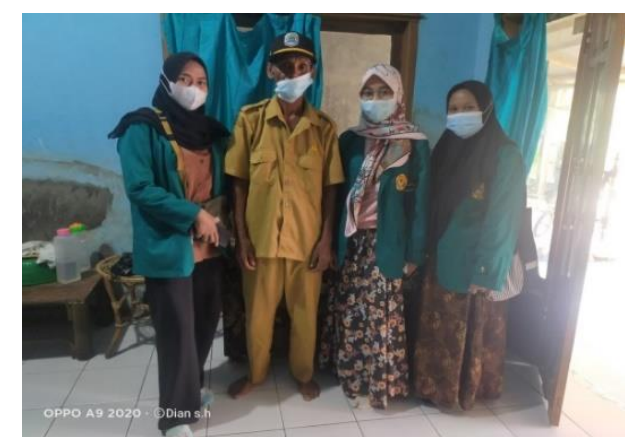

(b)

Gambar 4. Gerakan Sosial (a) Kepedulian peserta KKN dalam ikut serta kegiatan gotong royong dengan warga (b) Dalam upaya membantu pencegahan COVID-19, tim KKN ikut mendata warga terkait vaksinasi masal dan pemberian masker 


\subsection{Kunjungan Ke Pengusaha UMKM}

Desa Siluman terkenal akan industri mebel, maka dari itu kami tertarik untuk belajar mengenai pembuatan mebel. Di Desa Siluman terutama di Dusun Siluman I pada awalnya banyak buruh-buruh yang bekerja mebel di luar daerah setelah sekian puluh tahun mereka pulang ke Desa Siluman lalu mulai membuka usaha mebel kecil-kecilan, seiring berjalannya waktu omset penjualan mebel makin meningkat dan mulailah menyebar pengusaha-pengusaha kecil yang ada di Desa Siluman, sehingga makin banyaklah yang mencoba membuka usaha tersebut sampai sekarang.

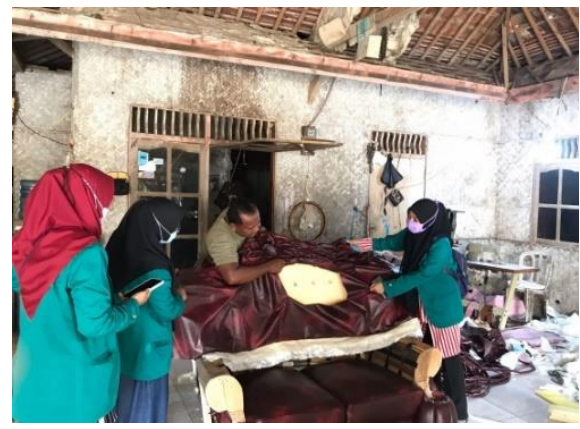

(a)

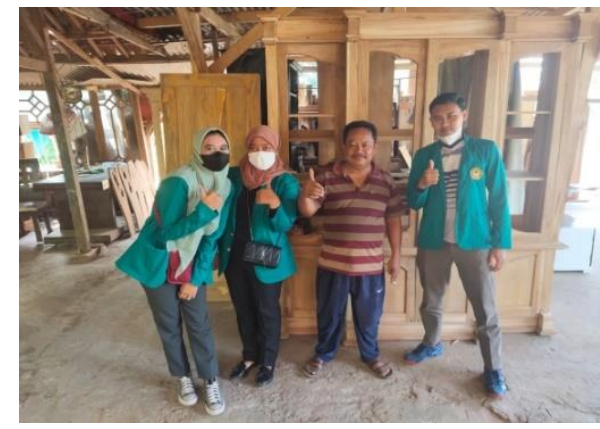

(b)

Gambar 5. Pengembangan UMKM (a) Tim KKN ikut belajar langsung pembuatan mebel yang merupakan salah satu mata pencaharian warga (b) Pembuatan mebel, lemari dan alat perkakas lainnya merupakan bentuk pengembangan ekonomi kreatif warga

\subsection{Mengadakan Kegiatan Webinar Tingkat SMP/MTs}

Di era digital saat ini masyarakat tidak dapat dipisahkan dengan yang namanya telepon cerdas maka dari itu kami ingin memaksimalkan penggunakan digital dan edukasi kepada peserta didik untuk meningkatkan kecerdasan dalam berteknologi digital dengan menggunakan aplikasi Zoom Meeting. Aplikasi Zoom adalah alat komunikasi berbasis video. Cara menggunakan Zoom tergantung perangkatnya lantaran aplikasi ini dapat diinstal pada desktop, ponsel, tablet, hingga sistem ruang. Aplikasi meeting daring menjadi pilihan bagi para pekerja yang terpaksa harus menyelesaikan pekerjaannya di rumah atau work form home karena pandemi COVID-19 (Tirto.id, 2021). Begitupun nilai manfaat yang dirasakan oleh para siswa sehingga menjadi pengerak pengembangan teknologi serta menjadi sarana belajar di manapun.

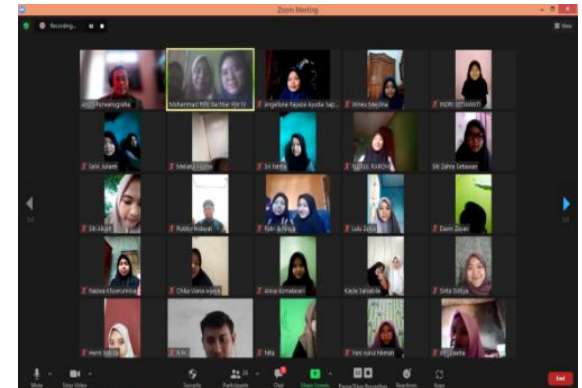

(a)

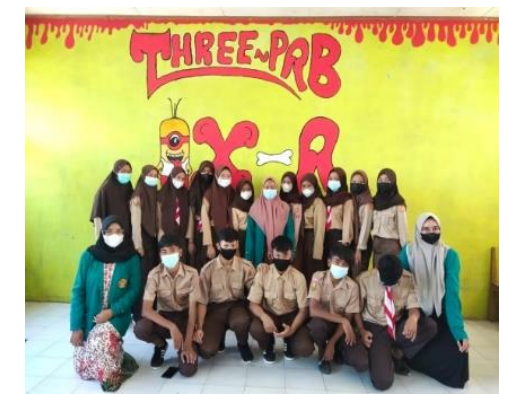

(b)

Gambar 6. Teknologi Pendidikan (a) Sebagai upaya edukasi literasi digital, mahasiswa bekerja sama dengan sekolah mengadakan Webinar (b) Para siswa/i SMPN 3 Pabuaran Subang sangat antusias dalam mengikuti kegitan Webinar

\subsection{Ikut Aktif Dalam Pengajian di Musala Nurul Ikhlas}

Ikut hadir dalam kegiatan pengajian yang ada di Desa Siluman dan mengadakan penyuluhan mengenai protokol COVID-19 dan melakukan pembagian masker pada jamaah yang lupa membawa masker ke mushola. 


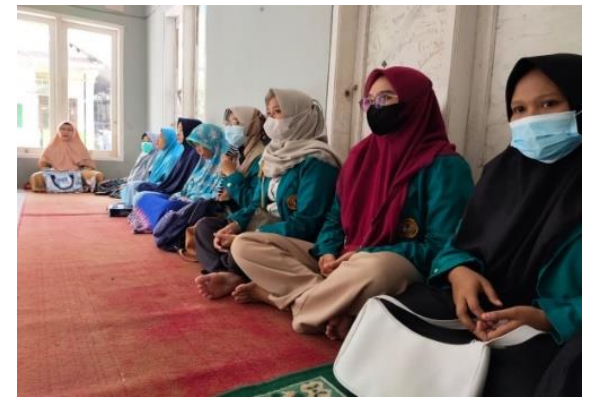

(a)

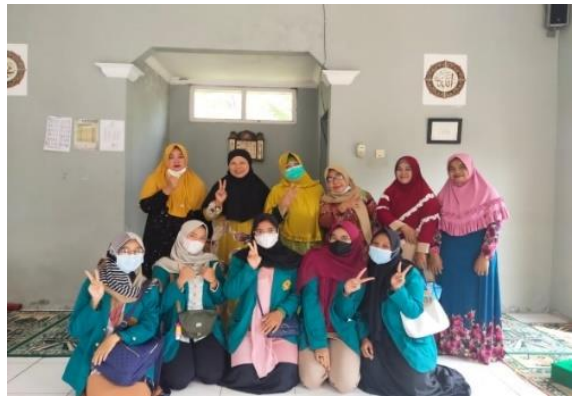

(b)

Gambar 7. Kegiatan Keagamaan (a) Kegiatan pengajian mingguan merupakan bagian meningkatkan silaturahmi warga dan pendidikan rohani (b) Setelah pengajian Tim KKN disambut baik oleh Pengurus Majlis Ta'lim Nurul Ikhlas Siluman Girang

\subsection{Mengikuti dan Mengadakan Kegiatan Senam}

Kegiatan dalam bidang kesehatan yaitu melakukan senam bersama ibu-ibu PKK dan anak-anak di Desa Siluman pada hari minggu.

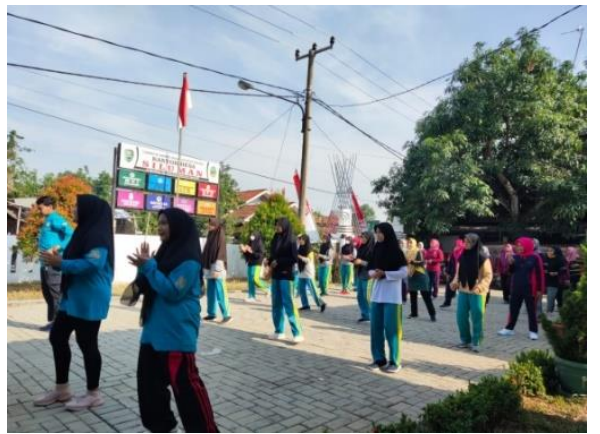

(a)

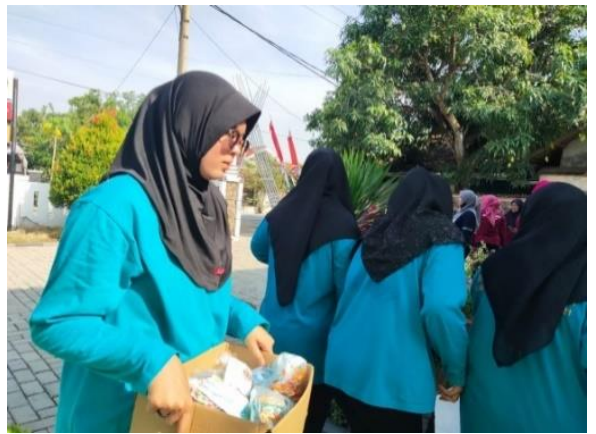

(b)

Gambar 8. Senam Sehat (a) Sebagai upaya mewujudkan badan yang kuat dan menjaga kesehatan

mahasiswa ikut aktif dalam kegiatan senam sehat bersama warga (b) Tim KKN tidak lupa memberikan masker gratis kepada warga sebagai upaya edukasi COVID-19 untuk hidup sehat

\subsection{Membantu Kegiatan Turnamen Bola Voli Tingkat Dusun Desa Siluman}

Kegiatan dalam bidang olahraga dan pemuda yaitu membantu kegiatn turnamenbola voli tingkat dusun Desa Siluman pada minggu terakhir kegiatan KKN.

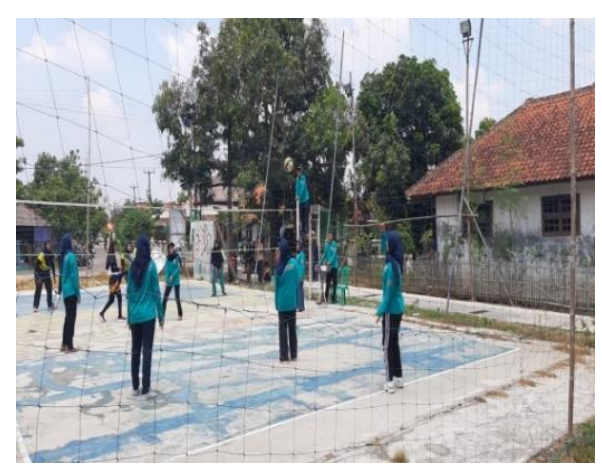

(a)

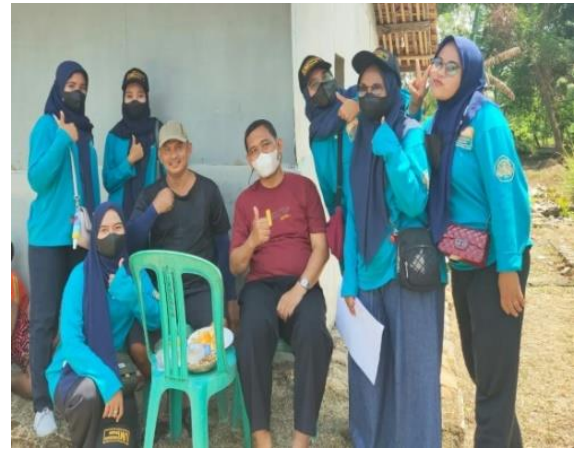

(b)

Gambar 9. Kegiatan Olahraga (a) Dalam peningkatan kebersamaan antar warga serta pemuda TIM KKN bersama Desa mengadakan pertandingan bola voli (b) Kegiatan pertandingan voli disambut baik oleh semua unsur masyarakat Desa Siluman

Secara umum dapat dikatakan proses pengabdian masyarakat melalui kegiatan Kuliah Kerja Nyata (KKN) Tematik COVID-19 Untuk Mewujudkan Merdeka Belajar Di Desa Siluman 
Kecamatan Pabuaran ini tidak memiliki kendala yang berarti. Hanya saja ada beberapa hal yang dapat menjadi sedikit hambatan terhadap kesempurnaan program ini: (1) kurangnya kesadaran masyarakat akan kesehatan sehingga tim KKN fokus dalam pelaksanaan program pencegahan COVID-19, melakukan kegiatan hidup sehat dan lingkungan bersih; dan (2) keterbatasan waktu pelaksanaan serta biaya yang terbatas, sehingga dalam pelaksanaan program KKN akan lebih efektif dan lebih menunjang dengan pelaksanaan program dalam waktu yang panjang serta pembiayaan yang lebih memadai. Dengan hadir dan terlaksananya pengabdian masyarakat melalui KKN Tematik Universitas Mandiri mampu mendorong kesadaran masyarakat dalam meningkatkan hidup yang sehat dengan membantu pelaksanaan protokol kesehatan, mampu meningkatkan gotong royong dalam masyarakat, mensemarakan kegiatan pengajian dan kegiatan keagamaan warga dan mengadakan kegiatan bimbingan belajar untuk siswa SD dan SMP dengan semarak merdeka belajar. Dengan demikian pelaksanaan KKN Desa Siluman Kab. Subang mampu merubah dan mengembangankan potensi desa, mengembangkan Sumber Daya Manusia, dan lebih adanya perhatian dalam kesejahteraan masyarakat, kebersamaan dan masyarakat yang sehat.

\section{KESIMPULAN}

Dengan tema "Tematik COVID-19 untuk mewujudkan merdeka belajar" membuat semakin banyak belajar tentang bagaimana kehidupan nyata (real action) di masyarakat, pengalaman dan pembelajaran baru yang bisa diterapkan dalam kehidupan sehari-hari. Mahasiswa dipandang sebagai orang yang serba tahu dan serba bisa oleh warga masyarakat oleh karenanya mahasiswa perlu untuk selalu meningkatkan kemampuan melalui aktualisasi dirinya. Kegiatan KKN ini membawa pengaruh positif untuk masyarakat yang ada di wilayah Desa Siluman. Kegiatan Kuliah Kerja Nyata (KKN) Universitas Mandiri di desa Siluman Kecamatan Siluman Kabupaten Subang ini telah mendapat sambutan, tanggapan dan perhatian yang baik dari Masyarakat, Guru, Kepala Sekolah, Tokoh Masyarakat dan Pejabat Pemerintahan Setempat

Hasil yang dicapai dalam pelaksanaan KKN Tematik ini adalah; membantu kegiatan (PTM) tatap muka terbatas, mengadakan bimbingan belajar, ikut serta dalam sosialisasi protokol kesehatan COVID-19, membantu kegiatan gotong royong, kunjungan ke pengusaha UMKM, mengadakan kegiatan Webinar Pendidikan, mengikuti kegiatan keagamaan di Musala Nurul Ikhlas, mengikuti dan mengadakan senam sehat warga, dan mengadakan kegiatan turnamen bola voli tingkat Dusun Desa Siluman. Dengan adanya kegiatan KKN Tematik ini diharapkan mampu mengoptimalkan kemampuan civitas Universitas Mandiri dalam pengembangan ilmu serta pengabdian di masyarakat. Dengan demikian kegiatan pengabdian masyarakat melalui KKN Tematik ini agar lebih ditingkatkan untuk lebih baik lagi agar hubungan mahasiswa, Lembaga Pendidikan, Lembaga Pemerintahan serta masyarakat menjadi lebih bersinergi dalam mewujudkan masyarakat Desa Siluman yang sehat, mandiri, unggul serta dinamis.

\section{DAFTAR PUSTAKA}

Indonesia, P. R. (2012). Undang-Undang Nomor 12 Tahun 2012 tentang Pendidikan Tinggi. Jakarta (ID): Sekretariat Negara.

Kesehatan, K. (2018). Hidup Sehat. https://promkes.kemkes.go.id/hidup-sehat

Kompas.com. (2021). Gotong Royong: Pengertian dan Manfaatnya. https://www.kompas.com/skola/read/2021/02/10/142520869/gotong-royongpengertian-dan-manfaatnya

Mulyadi, H. (2010). Diagnosis kesulitan belajar dan bimbingan terhadap kesulitan belajar khusus. Yogyakarta: Nuha Litera.

Pendidikan, M. (2020). Surat Edaran Pencegahan COVID-19 pada Satuan Pendidikan. https://www.kemdikbud.go.id/main/blog/2020/03/surat-edaran-pencegahan-covid19- 
pada-satuan-pendidikan

Rangki, L., \& Dalla, F. (2020). Upaya pencegahan dan penanggulangan transmisi covid 19 melalui program KKN Tematik Mahasiswa Universitas Halu Oleo. Journal of Community Engagement in Health, 3(2), 266-274.

RI, K. S. N. (2020). KEPRES Nomor 7 Tahun 2020 Tentang GUGUS TUGAS PERCEPATAN PENANGANAN CORONA VIRUS/DISEASE 2019 (COVID-19).

Tirto.id. (2021). Mengenal Aplikasi Meeting Zoom: Fitur dan Cara Menggunakannya. https://tirto.id/mengenal-aplikasi-meeting-zoom-fitur-dan-cara-menggunakannya-eGF7

Wiki, I. (n.d.). Siluman, Pabuaran, Subang. https://indo.wiki/content/Siluman, Pabuaran, Subang/Halaman_Utama.html 


\section{Halaman Ini Dikosongkan}

